Jurnal Teknologi Laboratorium

Vol.9, No.2, 2020, pp. $192-198$

ISSN 2580-0191(Online), ISSN 2338 - 5634(Print)

DOI: 10.29238/teknolabjournal.v9i2.243

Journal homepage: https://www.teknolabjournal.com/index.php/Jt//index

Original Research.

open - access

\title{
The effect of temperature and storage time of cuccal swabs on FGA and D13S317 loci with the STR PCR method
}

\section{Indah Nuraini Masjkur ${ }^{1 a^{*}}$, Evy Arfianti ${ }^{2 b}$, Ahmad Yudianto $^{1 c}$, Abdul Hadi Furqoni ${ }^{1,3 d}$, Qurrota A'yun $^{1 \mathrm{e}}$}

${ }^{1}$ Human Genetic Study Group Institute of Tropical Disease, Universitas Airlangga, Surabaya, Indonesia

${ }^{2}$ Faculty of Public Health, Universitas Airlangga, Surabaya, Indonesia

${ }^{3}$ Post Graduate Doctoral Program Degree Program, Faculty of Medicine, Universitas Airlangga,

Surabaya, Indonesia

a E-mail address: indahnuraini61@gmail.com

b E-mail address: avanty@rocketmail.com

cE-mail address: yudi4n6sby@yahoo.co.id

dE-mail address: cocohadi01@gmail.com

e E-mail address: qurrotaayun.elhuda@gmail.com

\section{HIGHLIGHTS}

- The evidence in the crime scene that DNA checks can perform has various characteristics

- FGA and D13S317 are short tandem repeat loci recommended by the FBI in human identification

- Temperature and storage time affect the quality of DNA in the buccal swab

\section{ARTICLE INFO}

\section{Article history}

Received Date: Oct $14^{\text {th }}, 2020$

Revised Date: Nov 02 ${ }^{\text {nd }}, 2020$

Accepted Date: Dec 28 ${ }^{\text {th }}, 2020$

\section{Keywords:}

Buccal Swab

DNA

Forensic

Short Tandem Repeat

\section{A B S T R A C T}

The samples used for forensic DNA analysis in living individuals are usually blood and buccal swabs, however blood collection requires an invasive method that can cause discomfort, thus a buccal swab can be a good choice for individuals examined, especially children. This study aimed to determine the effect of temperature and storage time of buccal swabs on the quantity of DNA as material for DNA examination in the forensic field. This study was a laboratory experimental to determine the effect after treatment. Buccal swab samples were 48 and divided into 2 temperature groups, namely room temperature $(\mathrm{RT})$ and $4^{\circ} \mathrm{C}$. The division of the temperature groups was also observed with time differences, namely 1, 3, 5, 7 days. EDNA extraction used the DNAzol method and DNA quantification used a Spectrophotometer. The PCR process was carried out with STR primers FGA and D13S317 loci. The visualization stage used acrylamide gel and silver staining.

The results of this study prove that there is an effect of temperature and storage time of buccal swab samples. The longer the treatment time, the lower the DNA level.With statistical analysis, it is obtained $p$-value of $<0.005$, it can be concluded that there are significant differences in DNA levels at the temperature and storage time treatments of the buccal swab sample. The results of DNA visualization at the FGA and D13S317 loci using the STR PCR method in this study can still be detected and can be used as a reference for examination in forensic cases.

This is an open-access article under the CC-BY-SA license.

*Corresponding Author:

Indah Nuraini Masjkur

Human Genetic Laboratory, Institute of Tropical Disease

Email: indahnuraini61@gmail.com 


\section{INTRODUCTION}

DNA stores all the information about genetics. Polymerase Chain Reaction (PCR) technique invention caused quite revolutionary changes in various fields. The results of the application of this PCR technique are called DNA fingerprint which is a description of the pattern of DNA pieces from each individual; because every individual has different DNA fingerprint. $., 2,3$ DNA fingerprint that is widely used as an individual identity is Short Tandem Repeat (STR). STR is an area that does not code in nuclear DNA and consists of 2-7 nucleotide sequences that are arranged repeatedly. Each STR locus has a polymorphism in the form of a difference in the number of repetitions in its partner allele and by using 13-20 STR loci, a person's identity can be determined. $, 4,5,6$

Any part of human body can be taken as a specimen because every nucleated cell in a person's body has identical DNA sequences, wherein a child receives essentially the same amount of genetic material from his/her biological mother and father (Mendel's law of inheritance). ${ }^{\underline{7}, \underline{8}}$ So far, specimens (samples) that are widely used in DNA testing to identify are blood/blood spots, sperm spots, vaginal swabs, buccal swabs. $\cdot, 10$ In general, the main choice used for DNA testing is blood. Blood specimens can be obtained from venous, arterial or capillary blood but this procedure requires an invasive procedure that can be uncomfortable for the individuals examined, and is impractical if used for large sampling. $\frac{11}{11}$

A buccal swab examination can be a good and convenient option for individuals examined, especially toddlers or children. Besides, samples from buccal swabs are more economical, practical, and easier to ship because they can be spared from the risk of tube rupture that can occur in delivery with blood specimens, but there are no specific standards regarding how long the temperature and storage time of buccal swab samples for DNA delivery so as to produce genomic DNA of good quality and an adequate amount for DNA examination. Hence this research on the effect of temperature and storage time of the buccal swab samples on the quality of DNA is the first step that will be used as a reference for future studies. This study aimed to obtain the optimal temperature and storage time and to produce good quality genomic DNA in sufficient quantities so that it can be used for STR PCR analysis. $\frac{12,13}{13}$

\section{MATERIAL AND METHOD Research design}

This study was a laboratory experimental, which is a method used to determine the effect after treatment in a study.

\section{Research population and sample}

The sample of this study is the DNA of male or female volunteers. The volunteers have previously filled out the Inform Consent form. Sample analysis was carried out at the Human Genetic Laboratory of the Institute for Tropical Diseases, Universitas Airlangga. This study used 48 samples of buccal swabs and divided into 4 groups of storage time with 12 samples each, namely 1, 3, 5, 7 days. Each storage time group has 2 temperature categories, namely 6 samples for room temperature and 6 samples for temperature of $4^{\circ} \mathrm{C}$. The research sample is the DNA of male or female volunteers. The volunteers have previously asked for approval to take buccal swabs as materials for research purposes at the Human Genetic Laboratory of the Institute for Tropical Diseases, Universitas Airlangga.

\section{Research materials and tools}

DNA isolation from buccal swabs using an organic method, namely DNAzol. $.14,15$ The extracted DNA would be quantified using a UV spectrophotometer $\underline{16}, 17,18$ In the PCR process using STR primers with FGA (5'-GGCTGCAGGGCATAACATTA-3 'and 5'ATTCTACGATTTGCGCTTCAGGA-3'), D13S317 (5'ATTACAGAAGTCTGGGGATGTGGAGGA-3 'and 5'-GGCAGCCCAAAAGACAGA-3') loci., , ,19 DNA amplification via PCR was carried out with the following protocol: FGA (Gene Ampr. PCR System 9700 Thermal Cycler, Promega Corp. 2001): initial denaturation; $96^{\circ} \mathrm{C}$ for 2 minutes, 
denaturation; $90^{\circ} \mathrm{C}$ for 1 minute, Annealing; $60^{\circ} \mathrm{C}$ for 1 minute, Extension; $70^{\circ} \mathrm{C}$ for 30 seconds; cycle 25 times. D13S317(Gene Ampr. PCR System 9700 Thermal Cycler, Promega Corp. 2001): Initial denaturation; $96^{\circ} \mathrm{C}$ for 1 minute, Denaturation; $94^{\circ} \mathrm{C}$ for 30 seconds, Annealing; $60^{\circ} \mathrm{Cfor} 30$ seconds, Extension; $70^{\circ} \mathrm{C}$ for 45 seconds; 30 times cycle, final extension $60^{\circ} \mathrm{C}$ for 30 seconds. Electrophoresis in this stage was using Polyacrylamid Gel Electrophoresis with silver staining. $\underline{20,21}$

\section{RESULTS AND DISCUSSION}

The results of the mean measurement of DNA levels using a UV-Visible Spectrophotometer for the research samples from the buccal swabs are as follows

Table 1. The results of mean DNA levels isolated from buccal swab samples

\begin{tabular}{llc}
\hline Treatment & & Mean DNA levels $(\mathrm{ng} / \mathrm{ul})$ \\
\hline Room temperature & 1 day & 1966.416667 \\
$(\mathrm{RT})$ & 3 days & 1773.333333 \\
& 5 days & 1519 \\
& 7 days & 1455.416667 \\
\hline Temperature $4^{\circ} \mathrm{C}$ & 1 day & 2996.583333 \\
& 3 days & 2307.666667 \\
& 5 days & 1969.333333 \\
& 7 days & 1593.083333 \\
\hline
\end{tabular}

Table 1, it is shown a tendency of decreasing DNA levels from buccal swab samples that have been through treatment time of $1,3,5,7$ days at room temperature and $4^{\circ} \mathrm{C}$. The decrease in DNA levels in this study indicate an effect on the length of treatment time, resulting in damage to the DNA structure. DNA damage caused by abnormal exposures, is caused by the irreversible breakdown of DNA hydrogen bonds. This condition results in damage to the purine - pyrimidine pair in DNA, where this purine - pyrimidine pair is the main component in the DNA structure. Another factor is the condition of the old sample and the presence of protein associations, such as (mentioned in) the study conducted by Hansen. $\underline{22}$ However, with this decrease in levels, the remaining DNA levels still allow for DNA profiling, which is at least 50 ng. In principle, the minimum level of DNA that can be used in DNA analysis depends on the need and the type of examination being performed. In this study, the DNA levels obtained from the buccal swab samples ranged from 1519-2996 ng/ul, so that it was still possible to carry out DNA analysis tests as was done by Fattorini. $\underline{18}$

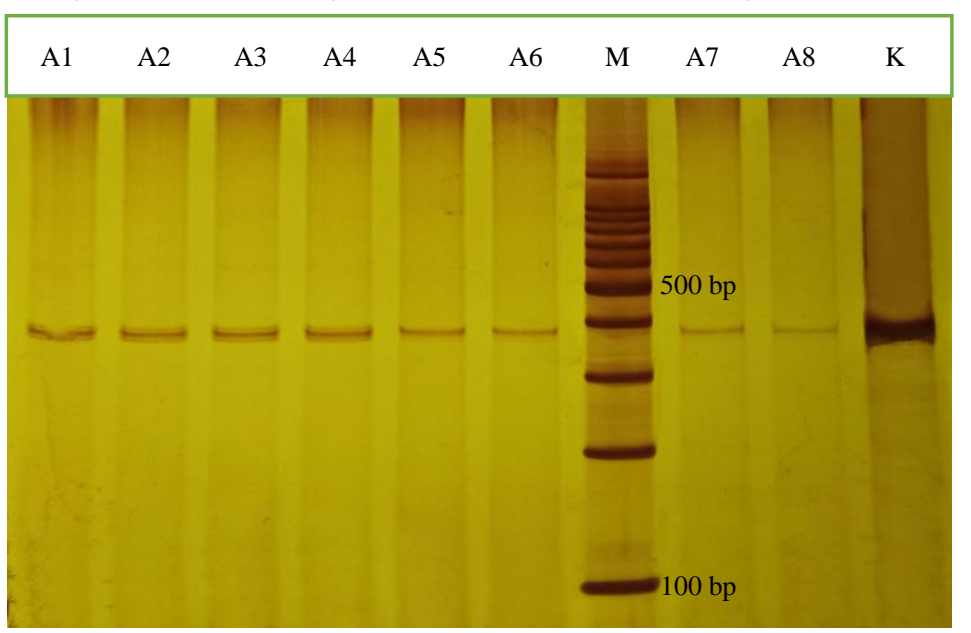

Information :

A1: sample day 1 at $4{ }^{\circ} \mathrm{C}$ temperature A2: sample day 3 at $4{ }^{\circ} \mathrm{C}$ temperature A3: sample day 5 at $4{ }^{\circ} \mathrm{C}$ temperature A4: sample day 7 at $4{ }^{\circ} \mathrm{C}$ temperature A5: Sample day 1 at room temperature A6: Sample day 3 day at room temperature

A7: Sample day 5 day at room temperature

A8: Sample day 7 at room temperature M: 100 bp marker

$\mathrm{K}$ : DNA control

Figure 1. The results of the FGA locus (322 - 444 bp) STR amplification in sample A 


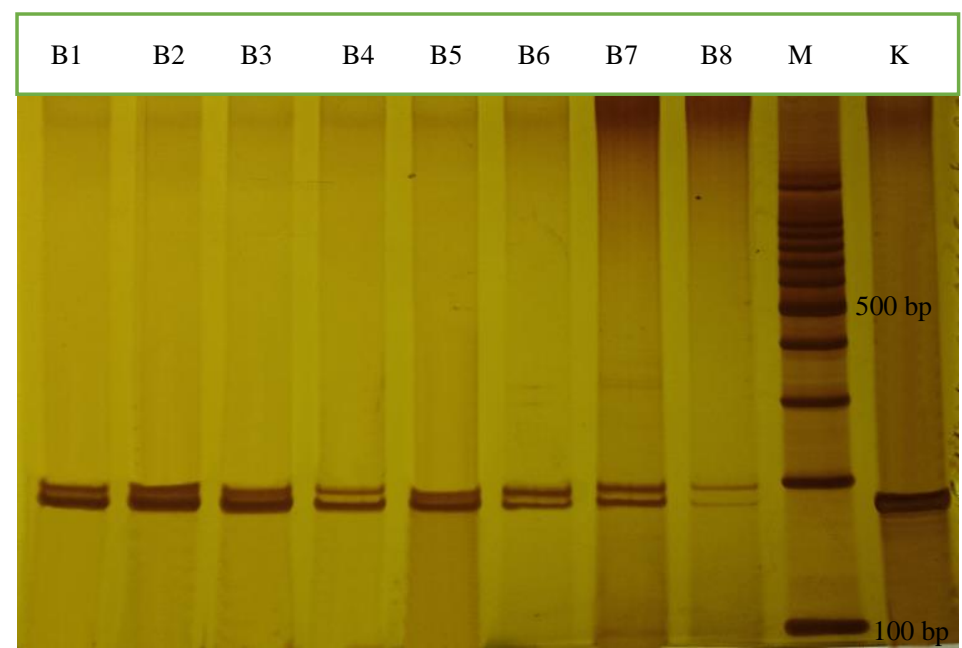

Information :

B1: sample day 1 at $4{ }^{\circ} \mathrm{C}$

B2: sample day 3 at $4{ }^{\circ} \mathrm{C}$

B3: sample day 5 at $4{ }^{\circ} \mathrm{C}$

B4: sample day 7 at $4{ }^{\circ} \mathrm{C}$

B5: Sample day 1 at room temperature B6: 3rd day sample at room

temperature

B7: Sample day 5 at room temperature B8: Sample day 7 at room temperature

M: 100 bp marker

$\mathrm{K}$ : DNA control

Figure 2. The result of the D13S317 locus (169-201 bp) STR amplification in sample B

The complete results of the detection of FGA and D13S317 loci on the buccal swabs DNA as an effect of temperature and storage time can be seen in the table 2.

Table 2. The results of detection of buccal swab DNA by STR PCR examination of the FGA and D13S317 loci

\begin{tabular}{llcccc}
\hline \multirow{2}{*}{ Treatment } & & \multicolumn{2}{c}{ FGA } & \multicolumn{2}{c}{ D13S317 } \\
\cline { 3 - 6 } & & Detected & Undetected & Detected & Undetected \\
\hline Room temperature & 1 day & 6 & 0 & 6 & 0 \\
& 3 days & 6 & 0 & 6 & 0 \\
& 5 days & 6 & 0 & 6 & 0 \\
& 7 days & 6 & 0 & 6 & 0 \\
\hline Temperature $4{ }^{\circ} \mathrm{C}$ & 1 day & 6 & 0 & 6 & 0 \\
& 3 days & 6 & 0 & 6 & 0 \\
& 5 days & 6 & 0 & 6 & 0 \\
& 7 days & 6 & 0 & 6 & 0 \\
\hline
\end{tabular}

The results of examining the effect of temperature and storage time on buccal swabs DNA in the FGA and D13S317 loci using the STR PCR method can be seen in Table 2. In all samples in this study, all are detectable. The visualization of PCR results using polyacrylamide gel in Figure 1 shows that all samples are detected in all treatments on the FGA locus (range between 322 - 444 bp) and in Figure 2 on the D13S317 locus (range between 169 - 201 bp). These results are in line with the research conducted by Manamperi et al that the D13S317 locus has a high polymorphic level based on the Patternity Index, Power of Discrimination, and Matching Probability. $\underline{23}$

\section{CONCLUSION}

Analysis of DNA identification in this study concluded that there is an effect of temperature and storage time of the buccal swabs on DNA levels. The longer the treatment time, the lower the DNA level is. This can be seen in the results of Kruskal Wallis analysis which obtain a $p$-value of $0.001(p<0.05)$. The effect of temperature and storage time of buccal swabs is not too disturbing to the DNA at the FGA and D13S317 loci with the STR PCR method. For further research, it is necessary to carry out PCR amplification of the buccal swab DNA at another STR locus and continue with a longer time so that it can be further utilized more widely in the field of forensic identification.

\section{DISCLOSURE STATEMENT}

The authors declare that they have no conflict of interest. 


\section{ACKNOWLEDGEMENT}

We would like to express our gratitude to Resources Department of Higher Education of Education and Culture Ministry of Indonesian Republic and Chief of Institute of Tropical Disease Airlangga University.

\section{FUNDING INFORMATION}

Human resources division. General directorate of Education and Culture ministry with 2020 annual budget.

\section{REFERENCES}

1. Wickenheiser R. Trace DNA: A Review, Discussion of Theory, and Application of the Transfer of Trace Quantities of DNA Through Skin Contact. J Forensic Sci. 2002;47(3)::442-450. doi:10.1520/JFS15284J.

2. Butler JM. Genetics and Genomics of Core Short Tandem Repeat Loci Used in Human Identity Testing. J Forensic Sci. 2006;51(2):253-265. doi:10.1111/1.15564029.2006.00046.x.

3. Coble MD, Butler JM. Characterization of new miniSTR loci to aid analysis of degraded DNA. $J$ Forensic Sci. 2005;50(1):43-53. http://www.ncbi.nlm.nih.gov/pubmed/15830996.

4. Ruitberg CM, Reeder DJ, Butler JM. STRBase: a short tandem repeat DNA database for the human identity testing community. Nucleic Acids Res. 2001;29(1):320-322. doi:10.1093/nar/29.1.320.

5. Aslam N, Rahman Z, Riaz-Ud-DIn S. Optimization of PCR Conditions to amplify Short Tandem Repeats ( STR ) of Human Genomic DNA. Int J Agric Biol. 2002;4(1). http://www. fspublishers.org/lssue.php?categorylD=15.

6. Novroski NMM, Wendt FR, Woerner AE, Bus MM, Coble M, Budowle B. Expanding beyond the current core STR loci: An exploration of 73 STR markers with increased diversity for enhanced DNA mixture deconvolution. Forensic Sci Int Genet. 2019;38(September 2018):121-129. doi:10.1016/i.fsigen.2018.10.013.

7. Reid TM, Peterson JW, Baird ML, Lee SC, Lee RF. The use of supplemental STR loci for resolving difficult family relationship cases. Forensic Sci Int Genet Suppl Ser. 2008;1(1):520-521. doi:10.1016/j.fsigss.2007.10.065.

8. Connor KLO, Ph D. Interpretation of DNA Typing Results for Kinship Analysis. Present 21st Int Symp Hum Identif. 2011. https://strbasearchive.nist.gov/fileDoc/strbasePDFS/pub pres/OConnor USCIS interpretation of DNA.pdf.

9. Butler JM. Short tandem repeat typing technologies used in human identity testing. Biotechniques. 2007;43(4):Sii-Sv. doi:10.2144/000112582.

10. Butler JM. Advanced Topics in Forensic DNA Typing: Methodology. U.S.A: Elsevier; 2012. doi:10.1016/C2011-0-04189-3.

11. Song $Y$, Fahs A, Feldman C, et al. A reliable and effective method of DNA isolation from old human blood paper cards. Springerplus. 2013;2(1):616. doi:10.1186/21931801-2-616.

12. Yudianto A, Sispitasri YE, Margaret N. Analysis of Earphone Swab Mitochondrial DNA as an Alternative Material for Identification Examination. Folia Medica Indones. 2017;52(3):169. doi:10.20473/fmi.v52i3.5446.

13. Al-Sammarraie HKI. Comparison between Two Different DNA Extraction Techniques Taken from Buccal Swabs Suitable for Genetic Analyzer. J Al-Nahrain Univ. 2016;19(3):108-113. doi:10.22401/JNUS.19.3.14.

14. Mackey K, Steinkamp A, Chomczynski P. DNA Extraction from small blood volumes and the processing of cellulose blood cards for use in polymerase chain reaction. $\mathrm{Mol}$ Biotechnol. 1998;9(1):1-5. doi:10.1007/BF02752692.

15. Chen H, Rangasamy M, Tan SY, Wang H, Siegfried BD. Evaluation of Five Methods 
for Total DNA Extraction from Western Corn Rootworm Beetles. Lalueza-Fox C, ed. PLoS One. 2010;5(8):e11963. doi:10.1371/journal.pone.0011963.

16. Doshi R, Day PJR, Carampin P, Blanch E, Stratford IJ, Tirelli N. Spectrophotometric analysis of nucleic acids: oxygenation-dependant hyperchromism of DNA. Anal Bioanal Chem. 2010;396(6):2331-2339. doi:10.1007/s00216-010-3461-x.

17. Pachchigar KP, Khunt A, Hetal B. DNA quantification. In: ICAR Sponsored Summer School on Allele Mining in Crops: Methods and Utility. ; 2016:4-7.

18. Fattorini $P$, Marrubini G, Bonin S, et al. Prolonged DNA hydrolysis in water: A study on DNA stability. Data Br. 2018;20:1237-1243. doi:10.1016/i.dib.2018.08.120.

19. Hameed IH, Ommer AJ, Murad AF, Mohammed GJ. Allele frequency data of 21 autosomal short tandem repeat loci in Mesan and Basra provinces in South Iraq. Egypt J Forensic Sci. 2015;5(4):150-156. doi:10.1016/i.ejfs.2014.10.003.

20. Benbouza H, Jacquemin J, Baudoin J, Guy M. Optimization of a reliable , fast , cheap and sensitive silver staining method to detect SSR markers in polyacrylamide gels. Biotechnol Agron Soc Environ. 2006;10(2):77-81. https://popups.uliege.be/17804507/index.php?id=1128.

21. Bassam BJ, Gresshoff PM. Silver staining DNA in polyacrylamide gels. Nat Protoc. 2007;2(11):2649-2654. doi:10.1038/nprot.2007.330.

22. Hanssen EN, Lyle R, Egeland T, Gill P. Degradation in forensic trace DNA samples explored by massively parallel sequencing. Forensic Sci Int Genet. 2017;27:160-166. doi:10.1016/j.fsigen.2017.01.002.

23. Manamperi A, Hapaurachchi C, Gunawardene NS, Bandara A, Dayanath D, Abeyewickreme W. STR polymorphisms in Sri Lanka: evaluation of forensic utility in identification of individuals and parentage testing. Ceylon Med J. 2009;54(3):85. doi:10.4038/cmj.v54i3.1201.

\section{SHORT BIOGRAPHY}

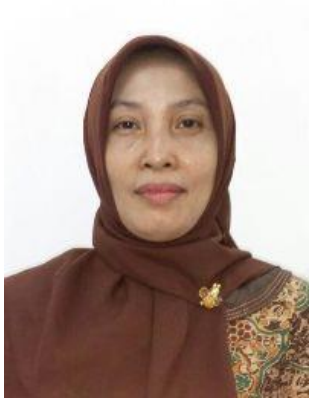

Indah Nuraini Masjur S.Si., M.Si was born in Surabaya by receiving forensic master tittle in 2011 from Airlangga University with consentration in biological moleculer forensic. Now, she works as laboratory technician at Human Genetic Laboratory Institute of Tropical Disease Airlangga University

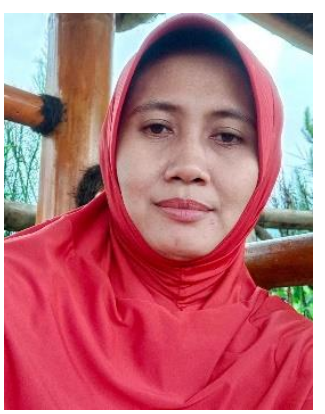

Evy Arfianti S.KM., M.Kes as laboratory technician at Public Health Faculty Airlangga University 


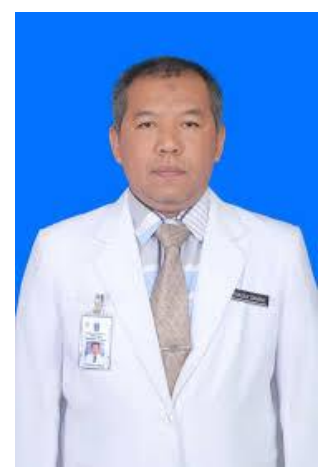

Dr. Ahmad Yudianto,dr,SpF,SH,M.Kes is Forensic Science and Medico-legal Specialist is a Lecturer and Head of the Forensic Science Master Program at the University of Airlangga since 2010/2011, and is a Specialist Doctor's Education Program since 2015. Forensic, Medico-legal, and Expert Witness since 2007 and at Human Genetic Laboratory Institute of Tropical Disease Airlangga University.

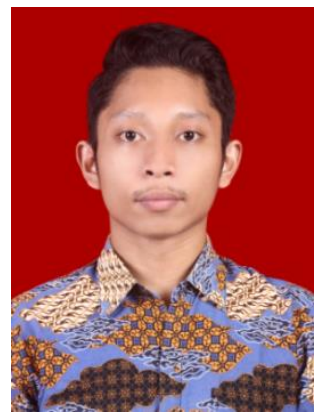

Abdul Hadi Furqoni, MFS, BScN, PhD student in Medical Science at School of Medicine, and a Researcher at Human Genetic Laboratory Institute of Tropical Disease Airlangga University

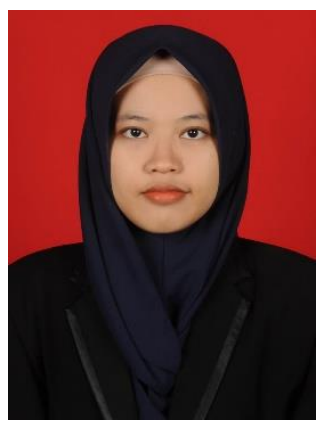

Qurrota A'yun S.KM as laboratory technician at Human Genetic Laboratory Institute of Tropical Disease Airlangga University 